Proc. Estonian Acad. Sci. Biol. Ecol., 2003, 52, 3, 346-359

\title{
A simulation of the Gulf of Finland ecosystem with a 3D model
}

\author{
Ivan A. Neelov ${ }^{\mathrm{a}}$, Tatyana R. Eremina ${ }^{\mathrm{b}}$, Alexey V. Isaev ${ }^{\mathrm{b}}$, \\ Vladimir A. Ryabchenko ${ }^{c *}$, Oleg P. Savchuk ${ }^{\mathrm{d}}$, and Roman E. Vankevich \\ ${ }^{a}$ Arctic and Antarctic Research Institute, 38 Ul. Beringa, 199397 St. Petersburg, Russia; \\ neelov@aari.nw.ru

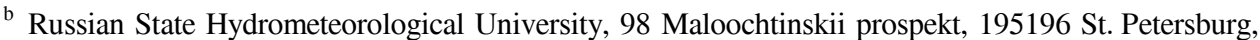 \\ Russia; tanya@sici.ru, isaev@rshu.ru \\ c St. Petersburg Branch, P. P. Shirshov Institute of Oceanology, 30 Pervaya Liniya, 199053 St. Peters- \\ burg, Russia \\ ${ }^{d}$ St. Petersburg Branch of the State Oceanographic Institute; present address: Department of Systems \\ Ecology, Stockholm University, S-106 91 Stockholm, Sweden; oleg@system.ecology.su.se \\ ${ }^{\mathrm{e}}$ Independent Investigation and Consulting Center, 5 Pereulok Dekabristov, 199155 St. Petersburg, \\ Russia; rvankevich@mail.ru
}

Received 11 December 2002, in revised form 17 April 2003

\begin{abstract}
Comparison of simulations with a 3D eutrophication model with observation data for the Gulf of Finland showed that the model reproduced satisfactorily typical features of seasonal variability in the Gulf of Finland system, especially in the surface layers. However, as the model is driven by real atmospheric forcing for 1995-2000 and by climatically average river runoff and nutrient loads, it was unable to simulate the exact succession of events occurring in the deep layers of the gulf during this period. More time-specific data are needed both for prescription of boundary conditions and as validation criteria in order to further calibrate the model and test its performance.
\end{abstract}

Key words: eutrophication, 3D modelling, hydrodynamics, biogeochemical cycles, validation, Baltic Sea, Gulf of Finland.

\section{INTRODUCTION}

The Gulf of Finland collects from its watershed about $20 \%$ of the terrestrial inputs of total nitrogen and phosphorus into the entire Baltic Sea (HELCOM, 1998). The eastern part of the gulf, which receives over $70 \%$ and $80 \%$ of the total phosphorus and nitrogen land loads to the gulf, respectively (Pitkänen et al., 2001), is even more subject to anthropogenic impact. The elevated trophic status of the gulf results in occasional cyanobacteria blooms, oxygen deficiency, macrofauna

*Corresponding author, Vladimir_Ryabchenko@VR5841.spb.edu 
kills, etc. (e.g. Perttilä \& Savchuk, 1996; Leppänen et al., 1997; Davidan \& Savchuk, 1997; Kahru et al., 2000; Pitkänen et al., 2001). The need for remedies is evident and the appeals for nutrient load reductions are not rare.

However, the development of scientifically sound water management recommendations for this area is extremely complicated and should take into account the major features of the biogeochemical nutrient cycles. The trophic status of both the entire gulf and its different regions is defined not only by the inputs into these specific areas but it also depends on the local nutrient transport and internal biogeochemical processes. For example, the easternmost part of the Gulf of Finland is phosphorus-limited (Pitkänen \& Tamminen, 1995) and displays a high phosphorus retention capacity (Heiskanen et al., 1999). Consequently, the reduction of the phosphorus land load into this area would hardly improve the situation there because the reduction can be compensated for by an increased phosphorus import from the west (Savchuk \& Wulff, 1999; Savchuk 2000). The long-range nutrient exchange with the Northern Baltic is comparable to the land inputs (Savchuk, 2002). But the exchange is also important because the propagation of saltier oxygen-depleted waters contributes to the development of oxygen deficiency (Davidan \& Savchuk, 1997) with corresponding phosphate release from anoxic sediments comparable to the annual phosphorus load (Pitkänen et al., 2001), which, in turn, triggers cyanobacteria blooms (Kahru et al., 2000). In such a complex environment, cost-effective recommendations, i.e. where, to what degree, and which nutrient's load should be reduced, must be based on scenario simulations by mathematical models.

Several models have been implemented to study the mechanisms of eutrophication and the effects of nutrient load reductions in the Gulf of Finland (Inkala et al., 1997; Savchuk et al., 1997a, b; Tamsalu et al., 1997; Inkala \& Pitkänen, 1999; Savchuk \& Wulff, 1999; Savchuk, 2000; Kiirikki et al., 2001). Although based on the same fundamental principles, these models are quite different in formulations; each has its advantages and deficiencies. Therefore, parallel use of such models was suggested in order to better substantiate the derived conclusions and important management recommendations (Savchuk et al., 1997c). Needless to say that before using any model for the assessment of an ecosystem's response to changes in nutrient loads it should be carefully verified against available data in hindcast simulations. We report here some results of comparison between available field data and simulation with a recently developed three-dimensional (3D) coupled hydrodynamic-biogeochemical model.

\section{THE COUPLED HYDRODYNAMIC-ECOSYSTEM MODEL}

The overall model has a modular structure including hydrodynamic and ecosystem modules.

The hydrodynamic module is a coupled ocean-sea ice model initially developed by Neelov (1996) and later modified and applied for the simulation of 
the seasonal variability of the Arctic Ocean and spreading riverine waters in it (Ryabchenko et al., 2001). In addition, the hydrodynamic module takes care of external impacts (atmospheric forcing and nutrient inputs). The sea ice model uses the dynamics and viscous-plastic ice rheology of Hibler (1979) and the thermodynamic energy balance from Parkinson \& Washington (1979) with the following modifications: (1) snow at the ice surface is introduced as an additional variable with other albedo values and (2) all melt water is assumed to flow down from the ice/snow surface into the ocean, creating an additional negative buoyancy flux. The sea circulation model is based on non-linear primitive equations of motion written in the hydrostatic and Boussinesq approximations, the equation of continuity, heat and salt transport equations, and the equation of the state of seawater in the form suggested by UNESCO (1981). The vertical mixing of the momentum, temperature, and salinity is treated using a $b-l$ turbulent closure scheme of 2.5 level (Mellor \& Yamada, 1982), where $b$ is the turbulent kinetic energy (TKE) and $l$ is the turbulent length scale.

Boundary conditions. At the sea surface, fluxes of momentum, heat, salt, and TKE are prescribed as being averaged over a grid cell to account for different contributions of ice-covered and open-water fractions of the cell. In particular, the wind stress at the open sea-atmosphere boundary and ice-atmosphere boundary is calculated from one and the same quadratic dependency on wind velocity but with different drag coefficients. The heat flux at the open sea-atmosphere boundary is calculated from the surface heat balance equation, the absorbed short-wave radiation being determined as a function of time from the beginning of year, latitude, cloudiness, near-surface air temperature, and sea surface albedo. Outgoing long-wave radiation and sensible and latent heat fluxes are represented as linear functions of the difference between the air and sea surface temperatures. The salt flux at the open sea surface is determined from the sea surface salinity and the difference between precipitation and evaporation. The heat flux at the ice-sea boundary is proportional to the difference between the seawater temperature at the top level of the model and the freezing temperature at the lower edge of ice. The salt flux at this boundary is calculated from the rate of ice and snow growth or melt. At the sea bottom, the vertical component of current velocity is equal to zero and no-flux conditions are specified for heat, salt, and TKE. The bottom friction stress is parameterized as a function of the horizontal velocity at a model level nearest to the bottom. At the lateral boundaries, no-slip condition for horizontal velocity and no-flux conditions for heat and salt fluxes are specified in the case of rigid boundaries (shores). At the river mouths, volume transport and temperature are prescribed and salinity is taken to be equal to 0 . In the straits, horizontal components of current velocity as well as temperature and salinity are prescribed.

The biogeochemical module describes biogeochemical nitrogen and phosphorus cycling in the coupled pelagic and sediment sub-systems. It was presented in detail in Savchuk \& Wulff (1996, 2001) and Savchuk (1997). This module contains eight pelagic state variables: phytoplankton, zooplankton, detritus 
nitrogen and phosphorus, ammonium, nitrate, phosphate, and dissolved oxygen. Two sediment state variables are formulated as bioavailable pools of nitrogen and phosphorus in the top active layer of sediments. The module simulates all the major fluxes occurring among these variables: primary production of phytoplankton and nutrient utilization, nitrogen fixation, zooplankton grazing and excretion, plankton mortality and sedimentation, mineralization of organic matter in the water column and by the sediments, denitrification and burial, photosynthetic aeration, and oxygen consumption. Parameterizations of the above processes are the same as in Savchuk \& Wulff (1996) and Savchuk (1997). The only exception is the parameterization of background light extinction due to components other than the model variables, e.g. mineral particles and dissolved "yellow substance". Since the explicit parameterization of such effects is far beyond the scope of this paper, the following simple relation between the background light attenuation $e x_{\mathrm{w}}$ and the bottom depth $h$ was assumed:

$$
\begin{array}{ll}
e x_{\mathrm{w}}=e x_{\mathrm{w} 0}+5 /(1+2 h) & \text { if } h \leq 20 \mathrm{~m}, \text { and } \\
e x_{\mathrm{w}}=e x_{\mathrm{w} 0}+0.122 & \text { if } h>20 \mathrm{~m},
\end{array}
$$

where $e x_{\mathrm{w} 0}=0.2 \mathrm{~m}^{-1}$, and $e x_{\mathrm{w}}$ in the open Gulf is equal to $0.322 \mathrm{~m}^{-1}$.

Boundary conditions. At the sea surface, the fluxes of nutrients and oxygen have to be prescribed. The flux of oxygen at the sea surface, $F_{\mathrm{O} 2}$, is determined as $F_{\mathrm{O} 2}=k_{\mathrm{g}}\left(c_{\mathrm{s}}-c_{\mathrm{w}}\right)$, where $k_{\mathrm{g}}$ is the coefficient of gas exchange depending on the wind velocity, $c_{\mathrm{s}}=c_{\mathrm{s}}(T, S)$ is the equilibrium oxygen concentration at the sea surface, $c_{\mathrm{w}}$ is the oxygen concentration in the water surface layer, $T$ and $S$ are temperature and salinity of the sea water. All the inputs from land can be divided into two types: inflowing with river waters and from point sources. In the model these inputs are combined and prescribed as mean monthly concentrations of organic and inorganic nutrients at the river mouths.

Model domain and grids. The model domain is the whole Baltic Sea with open boundaries at the Danish Straits. The integration of the model equations is performed on two nested grids. A spherical grid of $10^{\prime} \times 5^{\prime} \approx 10 \times 10 \mathrm{~km}$ is used for the whole Baltic Sea, and a finer rectangular grid $(d x=d y=3.7 \mathrm{~km})$, for the Gulf of Finland only. In both cases, the numerical approximation of the model equations is accomplished on so-called grid $B$. Namely, the horizontal components of current velocity, temperature, salinity, and pressure are computed on basic levels, the grid points for velocity components being shifted by half-step with respect to grid points for other variables. The vertical velocity is calculated on levels shifted by half-step in the vertical direction with respect to the basic levels. The above grids for the Baltic Sea and the Gulf of Finland were built so that all sea areas with actual bottom depths less than $3 \mathrm{~m}$ were "deepened" up to $3 \mathrm{~m}$. This version of the model had 27 layers, the boundaries between them being located at every $3 \mathrm{~m}$ from the sea surface down to $30 \mathrm{~m}$ and at every $6 \mathrm{~m}$ downwards to the bottom. Thus, the minimum number of layers in the model was 
one in some coastal grid points. In all other horizontal grid points the lowest, near-bottom boxes were of variable thickness. The values of state variables within the limits of such boxes were assumed to be invariable. The assumption allowed us to approximate the lateral exchange of momentum, mass, heat, salt, and tracers between the near-bottom boxes of different thickness so that the fluxes on different sides of the vertical boundary between these boxes had one and the same absolute values. This numerical procedure guarantees integral conservation of mass, heat, salt, and tracers in the case of a closed basin with noflux conditions at all boundaries.

\section{THE DESCRIPTION OF THE RUN}

The run was performed with the coupled ecosystem-hydrodynamic model in two stages. First, the solution on the above spherical grid for the whole Baltic Sea was obtained. At the second stage, the same model was integrated on the finer rectangular grid covering only the Gulf of Finland. The boundary conditions at the entrance to the gulf were taken from the solution obtained at the first stage for the whole Baltic Sea.

Atmospheric forcing was taken from the NCEP re-analysis database (Kalnay et al., 1996) as daily mean values of wind velocity components, total cloud cover, air temperature, precipitation, and relative humidity for 1995-2000. For the lack of contemporaneous data, the river discharge and nutrient concentrations from the Baltic Environment Database at Stockholm University (BED, http://data.ecology.su.se/Models/bed) for 1986-90 were combined with the point sources for 1995 from HELCOM (1998), integrated over the corresponding watersheds, and "concentrated" as mean monthly values for all the major rivers draining into the Baltic Sea (Kemijoki, Kokenmäenjoki, Ångermanälven, Norrström, Ljungbyån, Oder, Vistula, Neman, and Daugava) and into the Gulf of Finland (Narva, Luga, Neva, and Kymijoki). Since nutrient inputs into the Gulf of Finland decreased during the 1990s by 30-40\% (Pitkänen et al., 2001), the implementation of data from the late 1980s overestimates the nutrient load. In compensation, the atmospheric deposition of nutrients was neglected in the presented run.

In the Danish Straits, daily mean values for water flows, temperature, and salinity were prescribed from Hansen (1999) estimates for 1975-80, while nutrient exchange was neglected.

The initial conditions for temperature, salinity, oxygen, and inorganic nutrients were prescribed for 1 January 1995 as three-dimensional fields extracted from BED and averaged over December 1994 - January 1995 with the Data Assimilation System (Sokolov et al., 1997; http://data.ecology.su.se/Models/Das). The initial conditions for plankton and organic nutrients were given as uniformly distributed typically low winter values. Uniform values of bioavailable nitrogen $\left(20 \mathrm{~g} \mathrm{~N} \mathrm{~m}^{-2}\right)$ and phosphorus $\left(5 \mathrm{~g} \mathrm{P} \mathrm{m}^{-2}\right)$ were given as initial nutrient pools in the sediments. The initial sea current velocity and ice thickness were taken to be equal to 0 . 
Thus, the presented run started from rather realistic initial conditions and was driven by atmospheric forcing for 1995-2000, but all the other driving forces were prescribed as seasonal averages from previous periods. For comparison with the present simulation of the Gulf of Finland we used the observations extracted from BED with the SwingStations tool (Sokolov \& Wulff, 1999) for 1996-2000, when the available data are relatively abundant.

\section{RESULTS AND DISCUSSION}

Generally the simulated spatial and temporal variations of hydrographic variables are consistent with major features of the physical oceanography of the Gulf of Finland summarized by Alenius et al. (1998), including a fair quantitative agreement with observed seasonal and some of inter-annual variations (Fig. 1). Although salinity values increased westward with a growing distance from the Neva River, which is the major source of freshwater input to the Gulf of Finland (from 2-3 to 5-6 PSU at the surface and from 5 to 7.5-8 PSU in the near-bottom layers of the inner Neva estuary and central part of the gulf, respectively), the pattern of seasonal variations in these parts of the gulf was also similar to the western Gulf of Finland. The surface maximum is caused mainly by winter convection and to some extent by winter reduction of the freshwater discharge and ice formation. Ice melting and elevated freshwater discharge resulted in the summer minimum, which due to reduced mixing brought about a pronounced halocline, and together with a developed thermocline produced strong density stratification. Salinity variations in the deep layers followed an opposite pattern from the winter minimum to the late summer-autumn maximum, thus implying regular advection of saline waters from the Baltic Proper.

Computed temperatures are in a better agreement with observations than salinity, especially in the near-bottom layer (Fig. 1). This result is, at least partly, associated with the prescription of forcing functions in the present simulation. The water temperature depends strongly on the local atmospheric forcing, which was given exactly for the period considered (1995-2000), whereas the salinity distribution was formed mainly as a result of the Neva River's freshwater input, averaged for 1986-90, and the advection of saline waters from the Baltic Proper, which was also calculated using some climatic forcing rather than the real one for 1995-2000. The fact that the model reproduces the variability in the surface layers for 1996-2000 much better than in the deep layers is even more evident in the simulation of the biogeochemical cycles.

Similarly to hydrodynamics, the model reproduces reasonably the biogeochemical seasonal dynamics (Figs. 2 and 3). In the surface layers both the timing and the range of seasonal variations are captured rather well, especially for nitrate, although the increase in the winter nutrient maximum towards the northeast is underestimated in the model. This discrepancy might be caused by a combination of improper prescription of local nutrient inputs and inability to simulate some 
(a)
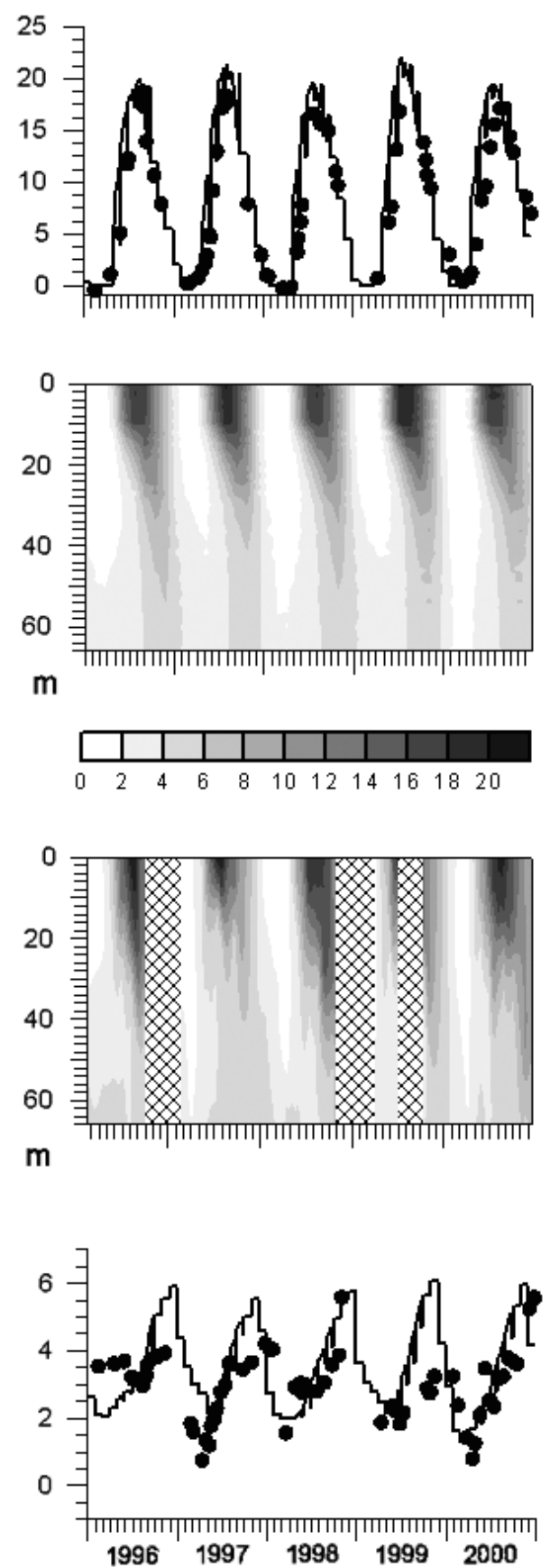

(b)
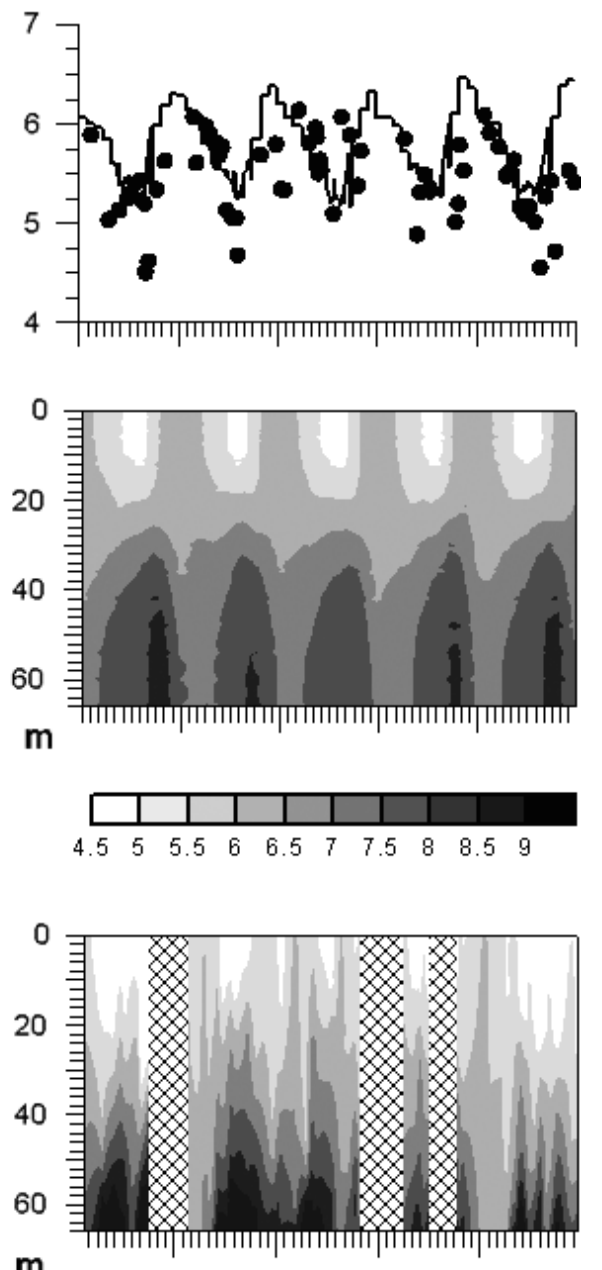

m

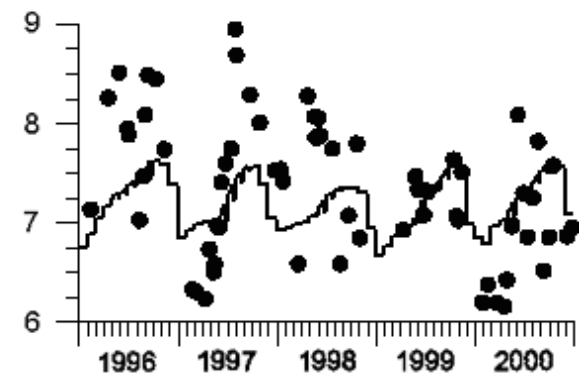

Fig. 1. The calculated against observed dynamics of temperature $\left(\mathrm{a}, \mathrm{C}^{\circ}\right)$ and salinity (b, PSU). Top to bottom: surface, simulated water column, observed water column, $60 \mathrm{~m}$ in the central Gulf of Finland (monitoring station LL7) in 1996-2000. 
(a)
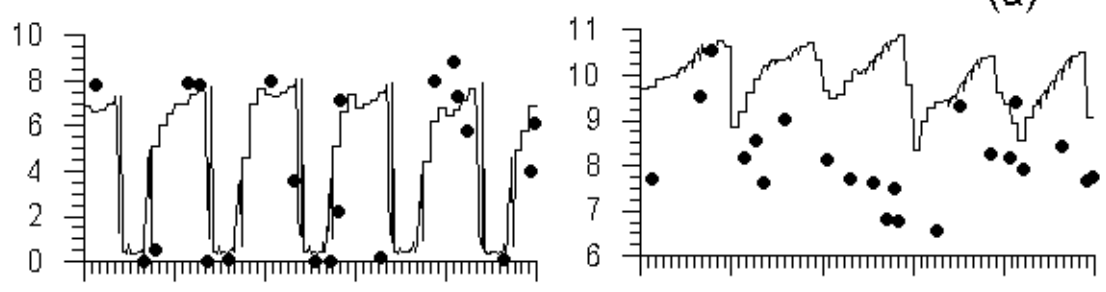

(b)
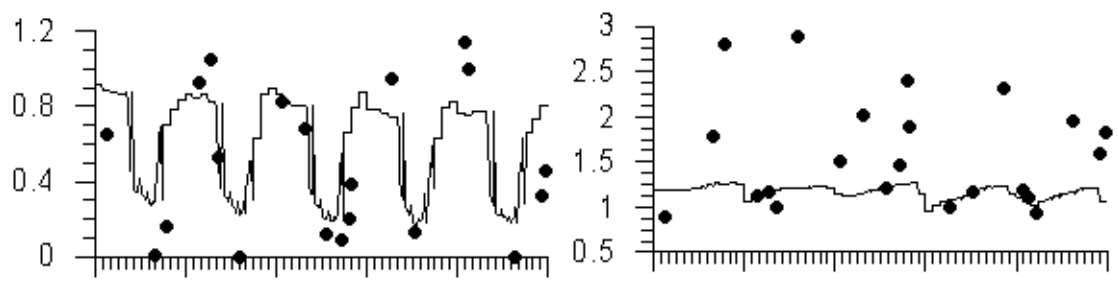

(c)
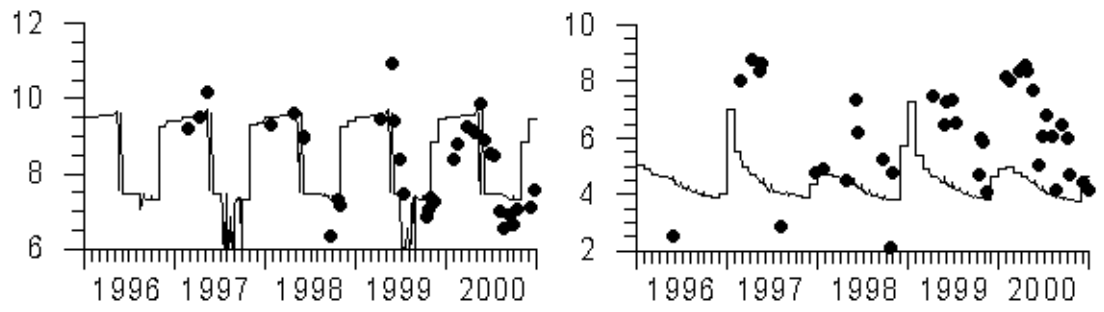

Fig. 2. The calculated against observed dynamics of oxidized nitrogen $\left(\mathrm{NO}_{2+3}\right)\left(\mathrm{a}, \mathrm{mmol} \mathrm{N} \mathrm{m} \mathrm{m}^{-3}\right)$, phosphate $\left(\mathrm{b}, \mathrm{mmol} \mathrm{P} \mathrm{m}{ }^{-3}\right)$, and oxygen $\left(\mathrm{c}, \mathrm{mL} \mathrm{L}^{-1}\right)$ at the surface (left column) and at $60 \mathrm{~m}$ (right column) at station LL7 in 1996-2000.

local features of the water dynamics in the Finnish archipelago with a present model resolution.

Simulated nutrient dynamics in the deep layers, which is most affected by the sediment-water interactions as well as by the exchange with the Northern Baltic, is less comparable to observations. Some of the inconsistencies may be explained by a very crude initial approximation of the sediment variables, e.g. the too high nitrogen content in the deep sediments resulted in an overestimated nitrogen release into the near-bottom waters of the central gulf compared to more reasonable levels in the shallow coastal area (cf. right panels of Figs. 2a and 3a). The inability to reproduce properly the advection of saltier oxygen-poor waters from the Northern Baltic with the consequent intensification of the phosphate release from the anaerobic sediments (Davidan \& Savchuk, 1997; Kahru et al., 2000; Pitkänen et al., 2001) seems to be more important. Although the model formulation accounts for an oxygen-dependent augmentation of the phosphate release, the 
simulated oxygen concentrations in the deep waters were still too high for this effect to take place. Even larger deviations between simulated and observed phosphate and oxygen concentrations in the near-bottom layer of coastal waters (Fig. 3b and 3c) can also be partly attributed to differences between the model and the natural bottom topography. The model depth here is $36 \mathrm{~m}$, while observations are from the monitoring station that is situated in a narrow "valley" deeper than $50 \mathrm{~m}$ (Mikko Kiirikki, pers. comm.) and can hardly be considered as representative of the surrounding shallower area.

The simulated seasonal dynamics of phytoplankton biomass corresponds to nutrient availability and distribution. For example, in 1997 the simulated spring bloom started in the Neva estuary, depleted there the winter reserves of phosphates within two weeks, in the next two weeks enveloped the entire gulf and stripped it of nitrate, while phosphates were left underutilized, thus setting preconditions for a summer cyanobacteria bloom (Fig. 4). In the model the

(a)
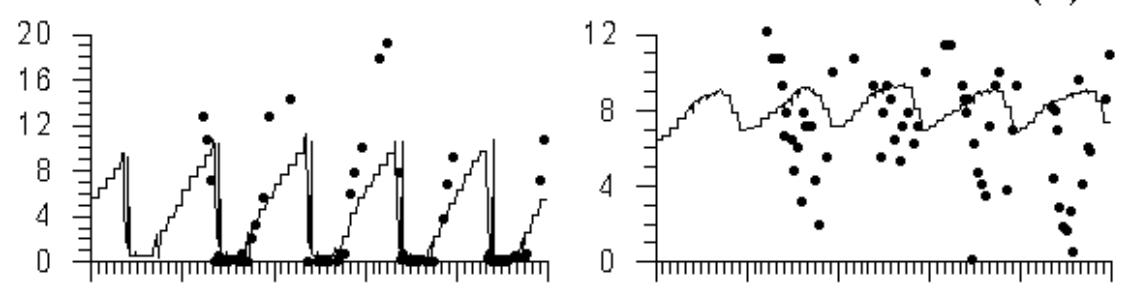

(b)

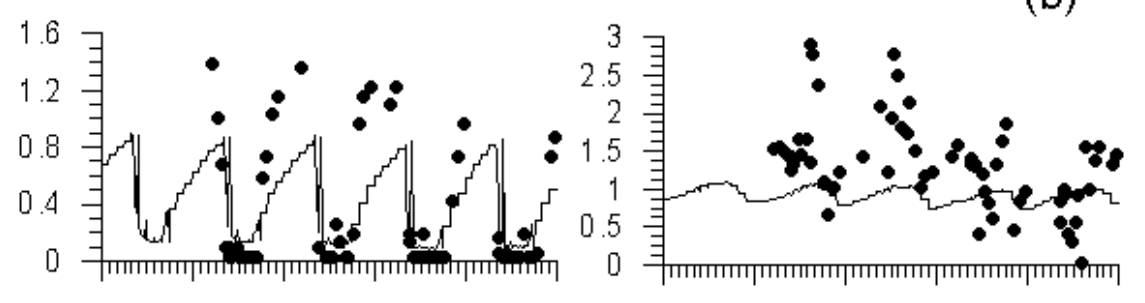

(c)

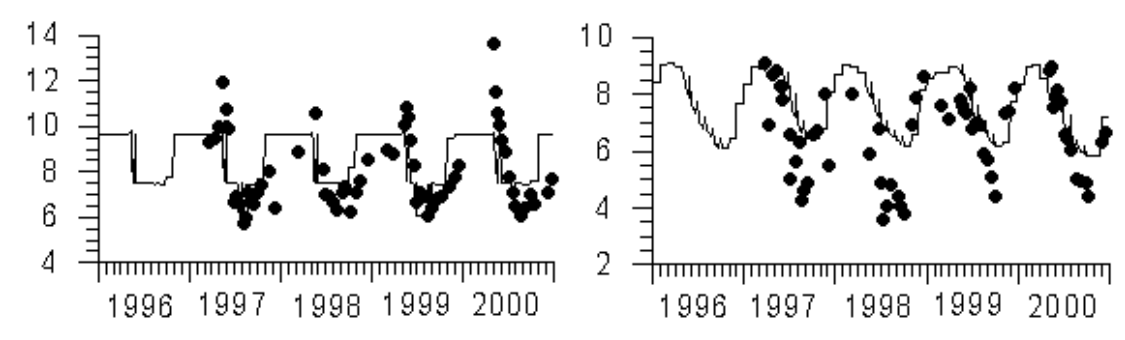

Fig. 3. The calculated against observed dynamics of oxidized nitrogen $\left(\mathrm{NO}_{2+3}\right)\left(\mathrm{a}, \mathrm{mmol} \mathrm{N} \mathrm{m}{ }^{-3}\right)$, phosphate $\left(\mathrm{b}, \mathrm{mmol} \mathrm{P} \mathrm{m}^{-3}\right.$ ), and oxygen $\left(\mathrm{c}, \mathrm{mL} \mathrm{L}^{-1}\right)$ at the surface (left column) and at $60 \mathrm{~m}$ (right column) at the Finnish intensive monitoring station $\left(60^{\circ} 23^{\prime} \mathrm{N}, 27^{\circ} 39^{\prime} \mathrm{E}\right)$ in $1996-2000$. 

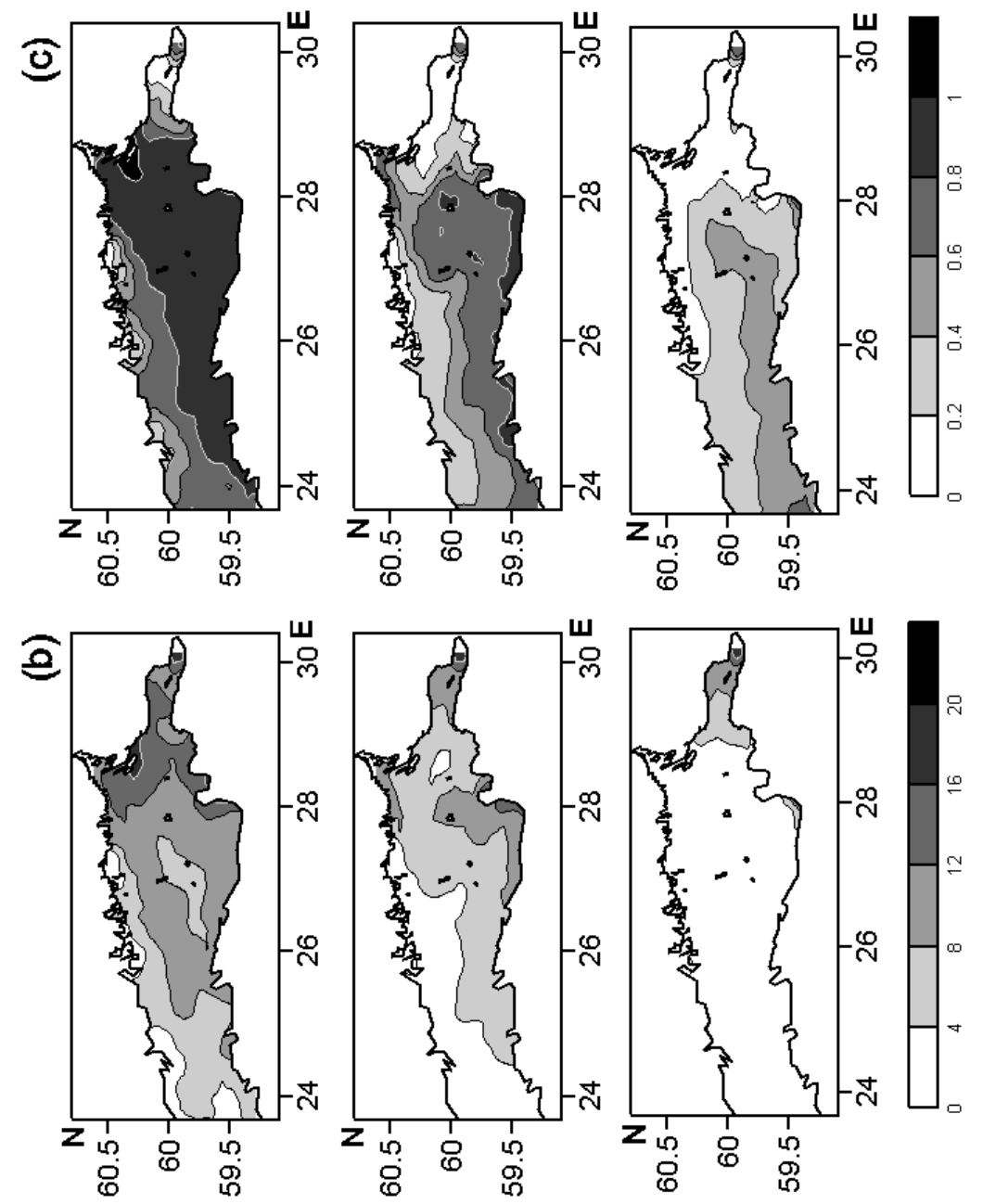

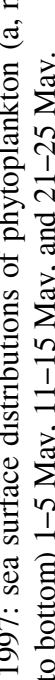

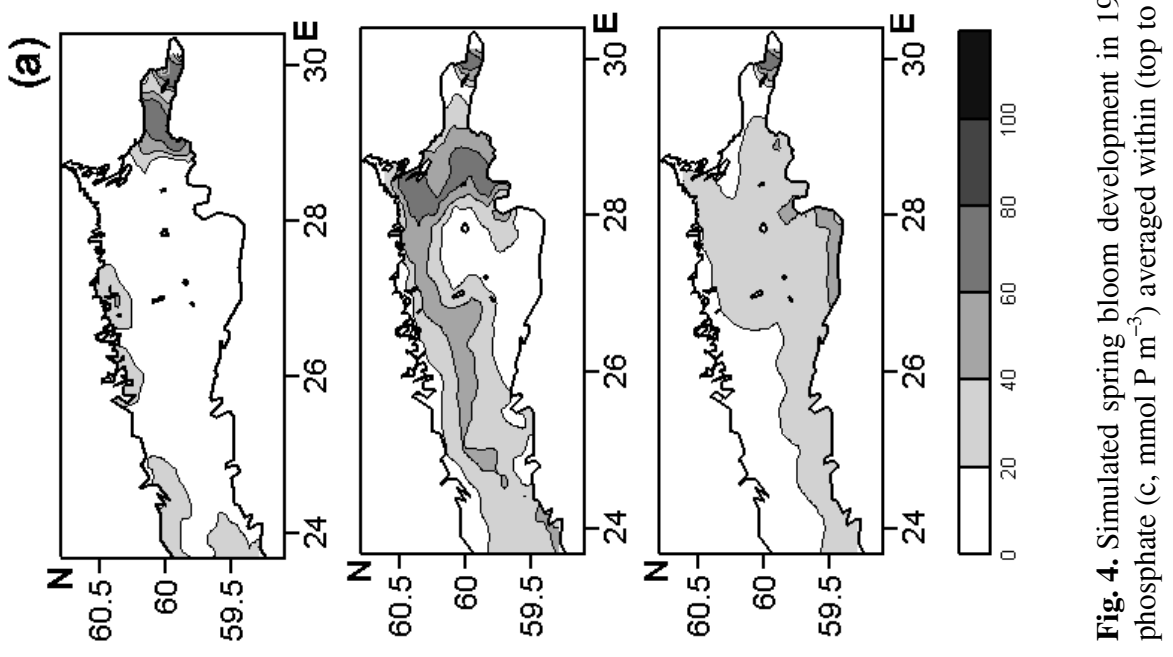


spring maximum values decrease westwards: from about $60 \mathrm{mg} \mathrm{N} \mathrm{m}^{-3}$ in the inner Neva estuary to $35-40 \mathrm{mg} \mathrm{N} \mathrm{m}^{-3}$ in the central gulf, respectively (Fig. 5). Assuming nitrogen content of $0.5 \%$ of the biomass of spring diatoms, these values would correspond to 12 and $7-8 \mathrm{~g} \mathrm{~m}^{-3}$ in wet weight units, respectively. With the empirical relation between algal biomass and chlorophyll (Inkala \& Pitkänen, 1999), the chlorophyll equivalents of the simulated biomass of 37 and 24-27 mg Chl $a \mathrm{~m}^{-3}$ are quite comparable to the reported ranges of
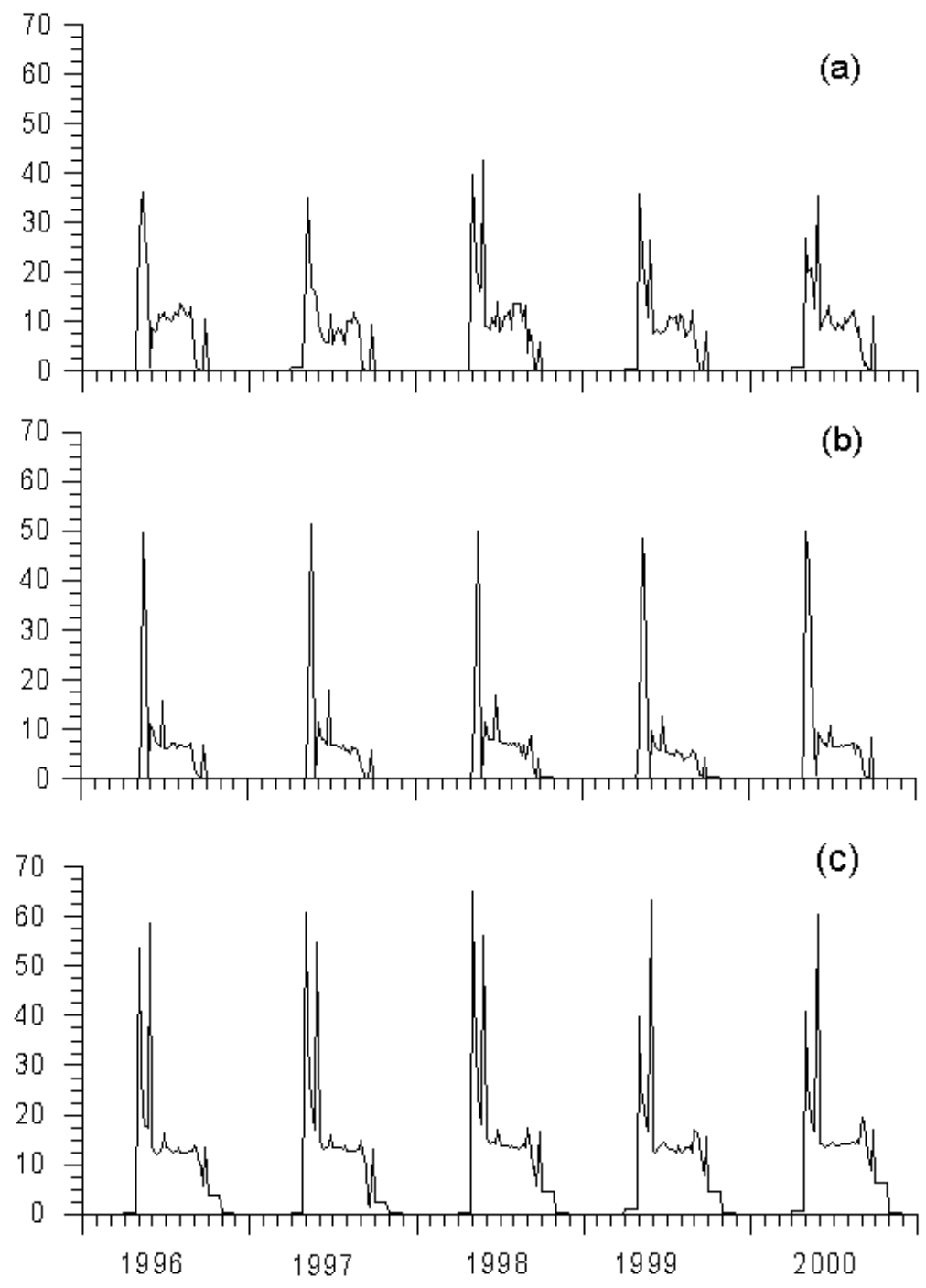

Fig. 5. Simulated dynamics of phytoplankton biomass $\left(\mathrm{mg} \mathrm{N} \mathrm{m}^{-3}\right)$ at the sea surface in the central $\left(\mathrm{a}, 59^{\circ} 67^{\prime} \mathrm{N}, 24^{\circ} 13^{\prime} \mathrm{E}\right)$, eastern (b, 60 $\left.10^{\circ} \mathrm{N}, 27^{\circ} 52^{\prime} \mathrm{E}\right)$, and easternmost (c, 60 $\left.02^{\prime} \mathrm{N}, 29^{\circ} 20^{\prime} \mathrm{E}\right)$ Gulf of Finland in 1996-2000. 
about 35-50 and 20-35 mg Chl $a \mathrm{~m}^{-3}$ (Kuosa et al., 1996; Baltic Sea Portal: http://www2.fimr.fi/en/itamerikanta.html).

Assuming 1\% nitrogen content in summer species and using the same empirical relation, the simulated summer biomasses in the easternmost part (10-15 mg Chl $a \mathrm{~m}^{-3}$ ), open eastern gulf (5-8 $\left.\mathrm{mg} \mathrm{Chl} a \mathrm{~m}^{-3}\right)$, and central gulf (7-12 $\mathrm{mg} \mathrm{Chl} a \mathrm{~m}^{-3}$ ) are also a good match to the observed ranges of 5-20, 5-10, and 5-10 $\mathrm{mg} \mathrm{Chl} a \mathrm{~m}^{-3}$, correspondingly (Kuosa et al., 1996; Baltic Sea Portal; Svetlana Basova, pers. comm.). In the model the summer biomasses in the phosphorus-limited easternmost area were maintained mostly by the riverine input, while in the central part the late summer maximum was associated with nitrogen fixation. Lower levels of summer biomass in the open eastern gulf were caused by lesser availability of nutrients both because this area is situated rather far from the Neva River input and because the nutrient concentrations there were close to Redfield equilibrium (see Fig. 4), thus precluding nitrogen fixation. Although there are some inter-annual variations in the seasonal development of simulated phytoplankton (Fig. 5), more time-specific data are needed for further calibration and validation of the model.

\section{CONCLUSIONS}

A 3D regional-scale eutrophication model for the Gulf of Finland was developed. Comparison to available observations shows that the model simulates typical features of the seasonal variability in the Gulf of Finland system fairly well. The results imply that the contribution of atmospheric physical forcing to the inter-annual variability of the biogeochemical nutrient cycling in the gulf is small. Consequently, the model driven by atmospheric forcing for 1995-2000 but with climatically average river runoff and nutrient loads was unable to reproduce the exact succession of events that occurred in the deep layers of the gulf during that period. Therefore, time-specific data are needed both for prescription of boundary conditions and as validation criteria in order to further test the model performance before it can be applied for studies of the effects of nutrient load reductions.

\section{ACKNOWLEDGEMENTS}

We gratefully acknowledge and thank all institutions that have contributed data to BED (http://data.ecology.su.se/Models/acknowle.htm), especially the Finnish Institute of Marine Research and the Finnish Environment Institute for the recent data from the Gulf of Finland. Svetlana Basova (North-Western Hydromet, Russia) is thanked for the generalized chlorophyll data in the eastern Gulf of Finland. This work was supported in part by the Finnish Environment Institute and through INTAS 97-99-674 contract. 


\section{REFERENCES}

Alenius, P., Myrberg, K. \& Nekrasov, A. 1998. Physical oceanography of the Gulf of Finland: a review. Boreal Environ. Res., 3, 97-125.

Davidan, I. N. \& Savchuk, O. P. (eds.). 1997. "Baltica” Project. Problems of Research and Modelling of the Baltic Sea Ecosystem. Issue 5. Ecosystem Models. Assessment of the Modern State of the Gulf of Finland. Gidrometeoizdat, St. Petersburg (in Russian).

Hansen, I. S. 1999. Establishment of Strait Fluxes 1970-90 for the Darss and Drogden Sills. Final Report to EU BASYS Project.

Heiskanen, A.-S., Gran, V., Lehtoranta, J. \& Pitkänen, H. 1999. Fate of nutrients (N, P) along the estuarine gradient of the River Neva in the eastern Gulf of Finland, Baltic Sea (Extended abstract). ICES, J. Mar. Sci., 56 (Suppl.), 161-164.

HELCOM. 1998. The third Baltic Sea pollution load compilation. Balt. Sea Environ. Proc., 70.

Hibler, W. D. III. 1979. A dynamic thermodynamic sea ice model. J. Phys. Oceanogr., 9, 815-846.

Inkala, A. \& Pitkänen, H. 1999. The effect of load reductions on algal biomass in the eastern Gulf of Finland estimated by the FINNALGA model. Boreal Environ. Res., 4, 357-366.

Inkala, A., Bilaletdin, Ä. \& Podsetchine, V. 1997. Modelling the effect of climate change on nutrient loading, temperature regime and algal biomass in the Gulf of Finland. Boreal Environ. Res., 2, 287-301.

Kalnay, E., Kanamitsu, M., Kistler, R. et al. 1996. The NCEP/NCAR 40-year reanalysis project. Bull. Amer. Meteor. Soc., 77, 437-471.

Kahru, M., Leppänen, J.-M., Rud, O. \& Savchuk, O. P. 2000. Cyanobacteria blooms in the Gulf of Finland triggered by saltwater inflow into the Baltic Sea. Mar. Ecol. Progr. Ser., 207, 13-18.

Kiirikki, M., Inkala, A., Kuosa, H., Pitkänen, H., Kuusisto, M. \& Sarkkula, J. 2001. Evaluating the effects of nutrient load reductions on the biomass of toxic nitrogen-fixing cyanobacteria in the Gulf of Finland. Boreal Environ. Res., 6, 131-146.

Kuosa, H., Makarova, S. \& Silina, N. 1996. Pelagic biology. In Gulf of Finland. Third Periodic Assessment of the State of the Marine Environment of the Baltic Sea, 1989-1993; Background Document (Perttilä, M. and Savchuk, O., eds.), pp. 52-56. Balt. Sea Environ. Proc., 64B.

Leppänen, J.-M., Pitkänen, H., Savchuk, O., Basova, S., Drabkova, V., Gran, V., Heiskanen, A.-S., Koponen, J., Spaer, I. \& Silina, N. 1997. Eutrophication and its effects in the Gulf of Finland. In Proc. Final Seminar of the Gulf of Finland Year 1996 (Sarkkula, J., ed.), pp. 31-49.

Mellor, G. L. \& Yamada, T. 1982. Development of a turbulence closure model for geophysical fluid problems. Rev. Geophys., 20, 851-875.

Neelov, I. A. 1996. A model of the Arctic Ocean circulation. In Proc. ACSYS Conf. on the Dynamics of the Arctic Climate System (Goteborg, Sweden, 7-10 November 1994), pp. 446-450. WCRP-94, WMO/TD, No. 760.

Parkinson, C. L. \& Washington, W. M. 1979. A large-scale numerical model of sea ice. J. Geophys. Res., 84, 311-337.

Perttilä, M. \& Savchuk, O. (eds.). 1996. Gulf of Finland. In Third Periodic Assessment of the State of the Marine Environment of the Baltic Sea, 1989-1993; Background Document, pp. 47-59. Balt. Sea Environ. Proc., 64B.

Pitkänen, H. \& Tamminen, T. 1995. Nitrogen and phosphorus as production limiting factors in the estuarine waters of the eastern Gulf of Finland. Mar. Ecol. Progr. Ser., 129, $283-294$.

Pitkänen, H., Lehtoranta, J. \& Räike, A. 2001. Internal nutrient fluxes counteract decreases in external load: the case of estuarial eastern Gulf of Finland, Baltic Sea. Ambio, 30, 195-201.

Ryabchenko, V. A., Alexeev, G. V., Neelov, I. A. \& Dvornikov, A. Yu. 2001. Spreading of riverine waters in the Arctic Ocean. Meteorol. Gidrol., 9, 61-69 (in Russian).

Savchuk, O. P. 1997. A model of the chemical-biological interactions. In "Baltica" Project. Problems of Research and Modelling of the Baltic Sea Ecosystem. Issue 5. Ecosystem Models. Assessment of the Modern State of the Gulf of Finland (Davidan, I. N. \& Savchuk, O. P., eds.), pp. 27-46. Gidrometeoizdat, St. Petersburg (in Russian). 
Savchuk, O. P. 2000. Studies of the assimilation capacity and effects of nutrient load reductions in the eastern Gulf of Finland with a biogeochemical model. Boreal Environ. Res., 5, 147-163.

Savchuk, O. P. 2002. Resolving the Baltic into 7 sub-basins: N and P budgets for 1991-99. Submitted to J. Mar. Syst.

Savchuk, O. \& Wulff, F. 1996. Biogeochemical Transformations of Nitrogen and Phosphorus in the Marine Environment - Coupling Hydrodynamic and Biogeochemical Processes in Models for the Baltic Proper. Systems Ecol. Contrib., Stockholm Univ., No 2.

Savchuk, O. \& Wulff, F. 1999. Modelling regional and large-scale response of Baltic Sea ecosystems to nutrient load reductions. Hydrobiologia, 393, 35-43.

Savchuk, O. P. \& Wulff, F. 2001. A model of the biogeochemical cycles of nitrogen and phosphorus in the Baltic. In A System Analysis of the Baltic Sea (Wulff, F., Rahm, L. \& Larsson, P., eds.), pp. 373-415. Springer, Berlin, Heidelberg, New York.

Savchuk, O. P., Andrejev, O. A. \& Sokolov, A. V. 1997a. Nitrogen and phosphorus biogeochemical fluxes in the Gulf of Finland simulated with the system of nested grids models. In Proc. Final Seminar of the Gulf of Finland Year 1996 (Sarkkula, J., ed.), pp. 97-99.

Savchuk, O. P., Andrejev, O. A., Sokolov, A. V. \& Chernysheva, E. S. 1997b. Modelling of the biogeochemical cycles in the Gulf of Finland ecosystem. In "Baltica” Project. Problems of Research and Modelling of the Baltic Sea Ecosystem. Issue 5. Ecosystem Models. Assessment of the Modern State of the Gulf of Finland (Davidan, I. N. \& Savchuk, O. P., eds.), pp. 47-64. Gidrometeoizdat, St. Petersburg (in Russian).

Savchuk, O., Koponen, J. \& Tamsalu, R. 1997c. Mathematical modelling of the eutrophication and its effects in the Gulf of Finland. In Proc. Final Seminar of the Gulf of Finland Year 1996 (Sarkkula, J., ed.), pp. 89-90.

Sokolov, A. \& Wulff, F. 1999. SwingStations, a web-based client tool for the Baltic environmental database. Comput. Geosci., 25, 863-871.

Sokolov, A. V., Andrejev, O. A., Wulff, F. \& Rodriguez-Medina, M. 1997. The Data Assimilation System for Data Analysis in the Baltic Sea. Systems Ecol. Contrib., Stockholm Univ., No. 3.

Tamsalu, R., Ennet, P., Kullas, T. \& Myrberg, K. 1997. The marine system model FINEST and its application to the Gulf of Finland ecosystem. In Proc. Final Seminar of the Gulf of Finland Year 1996 (Sarkkula, J., ed.), pp. 90-92.

UNESCO. 1981. Background papers and supporting data on the International Equation of State of Seawater 1980. UNESCO Techn. Papers Mar. Sci., 38.

\title{
Soome lahe ökosüsteemi kolmemõõtmelise mudeli lahendusi
}

\author{
Ivan A. Neelov, Tatyana R. Eremina, Alexey V. Isaev, \\ Vladimir A. Ryabchenko, Oleg P. Savchuk ja Roman E. Vankevich
}

Soome lahe ökosüsteemi kolmemõõtmelise mudeli ja mõõtmistulemuste võrdlus näitas, et mudel kirjeldab ökosüsteemi sesoonseid muutusi rahuldavalt, eriti hästi sobib see pinnakihile. Kuna atmosfääri mõju kohta olid aastate 1995-2000 tegelikud andmed, jõgede sissevoolu ja toitainete koormuste puhul aga klimaatilised keskmised, siis oli raske leida paremat kooskõla mudeli ja mõõtmistulemuste vahel, eriti sügavate kihtide vaatlusel. Rajatingimuste põhjalikumaks kirjeldamiseks ning mudeli kalibreerimiseks on vajalikud lisamõõtmised ja nende tulemuste põhjal koostatud aegread. 